\title{
Porcine zona pellucida vaccine immunocontraception of African elephant (Loxodonta africana) cows: A review of 22 years of research
}

\begin{tabular}{|c|c|}
\hline \multicolumn{2}{|c|}{$\begin{array}{l}\text { Authors: } \\
\text { Hendrik J. Bertschinger }{ }^{1} \mathbb{} \\
\text { Audrey Delsink }^{2} \\
\text { J.J. van Altena }{ }^{3} \\
\text { Jay F. Kirkpatrick }\end{array}$} \\
\hline \multicolumn{2}{|c|}{$\begin{array}{l}\text { Affiliations: } \\
\text { 'Department of Production } \\
\text { Animal Studies, University of } \\
\text { Pretoria, South Africa }\end{array}$} \\
\hline \multicolumn{2}{|c|}{$\begin{array}{l}{ }^{2} \text { School of Life Sciences, } \\
\text { University of KwaZulu-Natal, } \\
\text { South Africa }\end{array}$} \\
\hline \multicolumn{2}{|c|}{$\begin{array}{l}{ }^{3} \text { Global Supplies, Gauteng, } \\
\text { South Africa }\end{array}$} \\
\hline \multicolumn{2}{|c|}{$\begin{array}{l}{ }^{4} \text { The Science and } \\
\text { Conservation Center, Billings, } \\
\text { United States }\end{array}$} \\
\hline \multicolumn{2}{|c|}{$\begin{array}{l}\text { Corresponding author: } \\
\text { Hendrik Bertschinger, } \\
\text { henkbert@tiscali.co.za }\end{array}$} \\
\hline \multicolumn{2}{|c|}{$\begin{array}{l}\text { Received: } 26 \text { Oct. } 2017 \\
\text { Accepted: } 30 \text { May } 2018 \\
\text { Published: } 31 \text { July } 2018\end{array}$} \\
\hline \multicolumn{2}{|c|}{$\begin{array}{l}\text { How to cite this article: } \\
\text { Bertschinger, H.J., Delsink, A., } \\
\text { Van Altena, J.J. \& Kirkpatrick, } \\
\text { J.F., 2018, 'Porcine zona } \\
\text { pellucida vaccine } \\
\text { immunocontraception of } \\
\text { African elephant (Loxodonta } \\
\text { africana) cows: A review of } \\
22 \text { years of research', } \\
\text { Bothalia } 48(2) \text {, a2324. } \\
\text { https://doi.org/10.4102/abc. } \\
\text { v48i2.2324 }\end{array}$} \\
\hline \multicolumn{2}{|c|}{$\begin{array}{l}\text { Copyright: } \\
\text { ( ) 2018. The Authors. } \\
\text { Licensee: AOSIS. This work } \\
\text { is licensed under the } \\
\text { Creative Commons } \\
\text { Attribution License. }\end{array}$} \\
\hline \multirow[b]{2}{*}{ 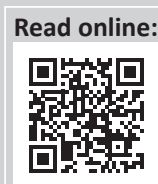 } & \\
\hline & $\begin{array}{l}\text { Scan this QR } \\
\text { code with your } \\
\text { smart phone or } \\
\text { mobile device } \\
\text { to read online. }\end{array}$ \\
\hline
\end{tabular}

Background: The native porcine zona pellucida (pZP) vaccine has been successfully used for immunocontraception of wild horses, white-tailed deer and approximately 90 zoo species for more than 25 years.

Objectives: To provide proof of concept and test contraceptive efficacy of pZP in African elephants. Once completed, test the population and behavioural effects on cows in the Greater Makalali Private Game Reserve (GMPGR). Following the GMPGR, test efficacy, population effects, safety and reversibility in 25 reserves with populations ranging from 9 to 700 elephants.

Method: Histological sections were reacted with anti-pZP antibodies to provide proof of concept. From 1996 to 2000, 21 and 10 cows were treated with pZP vaccine in the Kruger National Park (KNP) and monitored for pregnancy. Population effects of pZP with Freund's adjuvants (three vaccinations in Year 1 with one annual booster) were studied on 18 cows in the GMPGR. Another six game reserves with a total of 90 cows were added to the project. The project was then expanded to include another 18 reserves.

Results: Binding of anti-pZP antibodies to elephant zona proteins was demonstrated in vitro. The KNP provided efficacy results of $56 \%$ and $80 \%$, respectively. The contraceptive efficacy in the GMPGR and additional six reserves was $100 \%$ following calving of pregnant cows. Safety and lack of impact on social behaviour were demonstrated. In larger populations, efficacy was $>95 \%$.

Conclusion: Contraceptive efficacy and safety of pZP vaccine could be demonstrated in small to large populations. The methodology is now being implemented in approximately 800 cows on 26 reserves across South Arica.

\section{Introduction}

Immunocontraceptive methods make use of factors that are involved in crucial processes of reproduction. Such factors, known as antigens, are either reproductive hormones or proteins that are involved in fertilisation or other aspects of reproduction. The injection of such an antigen results in the production of specific antibodies, which then either neutralise the antigen (typical for hormones) or block a reproductive process such as fertilisation (Bertschinger \& Caldwell 2016:18-24). To improve the immune response, the antigens are combined with an adjuvant or adjuvants. Two immunocontraceptive methods, both essentially non-hormonal, have been extensively researched and used during the last 30 years in a variety of domestic and wildlife species (Bertschinger \& Caldwell 2016:18-24). They are the native porcine zona pellucida (pZP) vaccine and anti-gonadotrophin releasing hormone $(\mathrm{GnRH})$ vaccines. This article will report exclusively on pZP-immunocontraception of African elephants (Loxodonta africana). The pZP vaccine is made from pigs' ovaries and is thus a biological product of animal origin. The fertility control mechanism of a pZP vaccine is illustrated in Figure 1.

Immunocontraception with pZP was developed in the late 1980s; after initial laboratory animal trials, one of the first species it was tested in was the horse (Liu, Bernoco \& Feldman 1989:19-29). Following this, the first field trial was carried out on the wild horses (Equus caballus) of Assateague Island (Maryland and Virginia, USA; Kirkpatrick \& Turner 2008:513-519). Besides showing the contraceptive efficacy of the vaccine, the trial showed it to be safe when administered during pregnancy and, because of fewer pregnancies and supporting lactations, it increased the health and longevity of the mares (Kirkpatrick \& Turner 2007:1-8). Reversibility was also demonstrated. This varied according to the duration of annual boosters (Kirkpatrick \& Turner 2002:197-202). Typically, a mare is immunised twice (two to three weeks apart) during the first year which is followed by an 


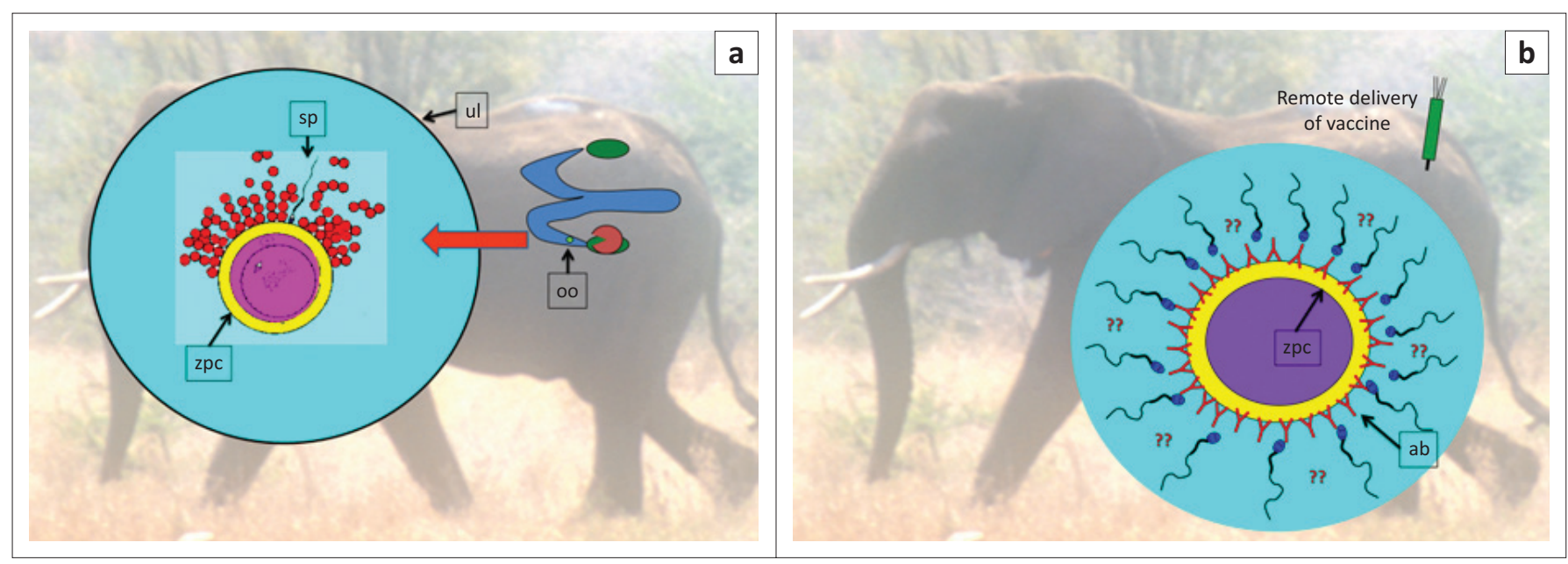

Source: Modified from Bertschinger, H.J. \& Caldwell, P., 2016, 'Fertility suppression of some wildlife species in southern Africa - A review', Reproduction in Domestic Animals 51(Suppl 1), 18-24. https://doi.org/10.1111/rda.12783

FIGURE 1: (a) Ovulated oocyte (oo) in the uterine lumen (ul). Sperm (sp) binding to a receptor site on the zona pellucida capsule (zpc). (b) Antibodies (ab) following vaccine delivery with a dart bind to the zona pellucida capsule $(\mathrm{zpc})$ and prevent sperm from attaching to receptor sites inhibiting fertilisation and pregnancy.

annual booster using 60 and later $100 \mu \mathrm{g}$ pZP per immunisation. The vaccine is usually administered remotely with a dart gun, which is important when dealing with many wildlife species. The vaccine is now used extensively in the USA to contracept wild horses. Following on this original work, pZPimmunocontraception has been used in more than 90 zoo and wildlife species (Kirkpatrick, Lyda \& Frank 2011:40-50). Some examples include white-tailed deer (Odocoileus virginianus) (Curtis et al. 2007:4623-4630), elk (Cervus canadensis) (Shideler et al. 2002:169-176), ovine and caprine species (Lyda et al. 2013:21-25) and even bears (Ursus sp.) (Lane et al. 2007:617625). In most species, including the horse, the mechanism of pZP action is attributed to blocking of sperm receptor sites by antibodies (depicted in Figure 1). Changes in ovarian oestradiol secretion are reported in mares (Kirkpatrick et al. 1992:437444), but in some species such as mice and cynomologus monkeys, permanent ovarian damage has been observed (Bagavant et al. 1999:635-642; Paterson et al. 1999:342-352).

More recently, the pZP vaccine has been used on elephants in South Africa, where they are primarily located within small $\left(<1000 \mathrm{~km}^{2}\right)$, fenced game reserves. These populations typically experience an $8 \%-10 \%$ per annum growth rate (Van Aarde et al. 2008:84-115) and left unchecked can double in numbers every 10-15 years (Mackey et al. 2006). Because of concerns around large densities of elephants negatively affecting the habitat within these game reserves (Caughley 1976; Owen-Smith 1988), the lack of new areas suitable for elephants within South Africa and culling not deemed publicly acceptable, the need for non-lethal population control methods arose. Immunocontraception with $\mathrm{pZP}$, if shown to be effective, appeared to be an appropriate method to achieve this.

\section{Porcine zona pellucida immunocontraception in African elephants}

The immunocontraceptive vaccine pZP is produced from pigs' ovaries obtained from pig abattoirs (approved by the
Department of Agriculture, Forestry, Fisheries [DAFF] in South Africa). The final product consists of solubilised zona pellucida proteins with a given concentration (Dunbar, Waldrip \& Hendrik 1980:356-365). The product is lyophilised and, before use, reconstituted with sterile injection water. Early work on elephants in the Kruger National Park (KNP) and Greater Makalali Private Game Reserve (GMPGR; 20002002) was carried out with pZP vaccine imported from the USA (Science and Conservation Center, Billings, Montana, USA). In 2003, the pZP Laboratory (now called Veterinary Population Management Laboratory, Section of Reproduction, Department of Production Animal Studies, University of Pretoria, Onderstepoort, South Africa) started producing the vaccine. Since 2003, it has supplied all pZP vaccine for elephant contraception in South Africa with approval from DAFF and the Medicines Control Council.

\section{Proof of concept in African elephants}

In 1995, Kirkpatrick, Fayrer-Hosken and Bertschinger decided to test the feasibility of using pZP vaccine for contraception of elephant cows. The first study was aimed at providing proof of principle, which involved two steps. The first step was to observe if anti-pZP antibodies could recognise the elephant zona pellucida capsule. Anti-pZP antibodies were obtained by immunising rabbits with pZP. Briefly, the diluted rabbit antiserum was reacted with histological sections from African elephant cows. After washing the sections, a labelled secondary antibody (protein A-10 nm gold) was added. This was followed by washing and addition of standard silver to enhance the gold staining. Immunogold staining within the capsule would indicate that the rabbit anti-pZP antibodies recognised the elephant zona proteins. The reaction was positive thus providing proof of principle (Fayrer-Hosken et al. 1999:835-846). The second step was to observe the antibody response of captive African $(n=2)$ and Asian $(n=1)$ cows to pZP vaccine. The treatment consisted of a primary and booster vaccination (both $400 \mu \mathrm{g}$ pZP with $5 \mathrm{mg}$ trehalose dicorynmycolate [TDCM] adjuvant) four weeks later. This was followed by 
a second booster ( $600 \mu \mathrm{g}$ pZP with $5 \mathrm{mg}$ TDCM adjuvant) 10 months later. The antibody titres were monitored over a period of 750-800 days. All cows responded to the primary immunisation and first booster; however, the response to the second booster 10 months later was particularly marked. Much higher titres that were far better maintained over the next year were obtained (Fayrer-Hosken et al. 1999:835-846). Consequently, proof of principle had been demonstrated (Fayrer-Hosken et al. 1999:835-846).

\section{First porcine zona pellucida immunocontraception field study in the Kruger National Park}

The first elephant immunocontraception field trial was carried out in the KNP in 1996 (Fayrer-Hosken et al. 2000:149). Elephant cows presumed to be non-pregnant based on the sizes of their calves at foot were immobilised and examined for pregnancy using transrectal ultrasound. Only confirmed non-pregnant cows were used during the studies and all were either radio-collared or collared with a plain strap to aid in identification and to assist in relocation. During Trial 1, 21 cows (treatment) were primed with pZP $(600 \mu \mathrm{g})$ and TDCM adjuvant followed by two booster immunisations, six weeks and six months after primary treatment. Eighteen cows (control) were treated with a placebo. One year later, $44 \%$ and $89 \%$ of the treated and control cows were pregnant, respectively. Although the results were encouraging, they were somewhat disappointing (Fayrer-Hosken et al. 2000:149) when compared to results that had been achieved in mares (Kirkpatrick \& Turner 2008:513-519). A second trial (Trial 2) was conducted on 10 additional cows using a modified protocol requiring the cows to be boosted after intervals of two and four weeks, respectively. Ten months later, only 2 out of 10 cows were pregnant (Fayrer-Hosken et al. 2000:149). In a third trial, four of the treated cows found to be nonpregnant in Trial 1 after one year were boosted with pZP and another three treated cows were given placebo treatment. Twelve months later, all four pZP-treated cows were nonpregnant, but showed signs of ovarian activity on transrectal ultrasound examination. The three cows that were placebotreated had conceived. This part of the study demonstrated that annual treatment could prolong the contraceptive effect and in the absence of treatment, short-term reversibility occurred (Fayrer-Hosken et al. 2000:149).

\section{First population control study at Greater Makalali Private Game Reserve}

The next phase was to test pZP-immunocontraception as a tool for elephant population control within small, enclosed conservation areas (Delsink et al. 2006:403-405, 2007:25-30; Delsink \& Kirkpatrick 2012). This study was undertaken on the elephant population of the GMPGR. The objective was not to completely terminate reproduction, but to slow down the population growth rate through a defined treatment protocol. However, to achieve reproductive control, all cows $(n=18)$ of breeding age (approximately 12 years and older) were vaccinated after being individually identified.
In Year 1 (2000), these cows were immunised with $600 \mu \mathrm{g}$ pZP mixed with Freund's complete modified adjuvant (FCMA) followed by two boosters (600 $\mu \mathrm{g}$ pZP each) with Freund's incomplete adjuvant (FIA) at two- to three-week intervals. Vaccine was delivered with a drop-out dart, initially delivered from the ground, fired into the semimembranous or semitendinosus muscle mass and later from a helicopter delivered into the rump muscles (further details provided below). Annual boosters were delivered using the same dose. In Year 3 (2002) and onwards, until some cows were taken off annual boosters, no calves were born, thereby achieving reproductive control and demonstrating a contraceptive efficacy of $100 \%$ using this protocol.

In 2003, the primary dose of pZP was reduced to $400 \mu \mathrm{g}$ and boosters to $200 \mu \mathrm{g}$, respectively, in new treatment cows. There were two reasons to change the dose in 2003 and onwards. The decision to use a dose of $600 \mu \mathrm{g}$ in the KNP and for the years 2001-2002 in the GMPGR was empirical and made to maximise the chances of success. Dose of drug or vaccine used does not increase relative to the weight of the animal. As an example, for protection against diseases like distemper and rabies in dogs the same dose is used irrespective of size (Chihuahua, $2.5 \mathrm{~kg}$ vs Great Dane, $>50 \mathrm{~kg}$ ). Studies on the efficacy of $\mathrm{pZP}$ in mice and horses used total doses of $\approx 25 \mu \mathrm{g}$ and $100 \mu \mathrm{g}$, respectively (Kirkpatrick et al. 1995:411-418; Millar et al. 1989:935-938). The second reason was to reduce the cost of treatment as production of native $\mathrm{pZP}$ vaccine is labour intensive and expensive. The interval between the primary and booster immunisation was increased to five weeks, which allows a better immune response (Castiglione et al. 2012:9). Specifically, it was hypothesised that lower doses would not reduce efficacy of contraceptive treatment. In addition, the vaccination protocol was revised and young cows without calves at foot were not treated until they had produced their first calf to address the individual and herd requirements from a demographic and social perspective.

During the first two years, calves continued to be born, indicating that pZP-immunocontraception had no negative effect on pregnancies and, with a gestation period of 22 months, calving continued until the last cows pregnant at inception of the programme had calved. This observation is important from two perspectives. Firstly, it indicates that the vaccine is safe during pregnancy and, secondly, continued calving during the first two years will affect the management plan and must be considered (Delsink et al. 2006:403-405). The changes in the vaccine dosage for primary and booster treatments did not change the vaccine efficacy.

By 2016, the GMPGR population growth rate had dropped to between $1 \%$ and $3 \%$ from an annual average growth rate prior to implementation of 8.9\% (Delsink et al. 2006:403-405). As cows are only treated after the birth of their first calves, and four cows reversed and calved after being removed from longer term treatment, births have purposefully been included in the long-term GMPGR elephant management strategy for social and demographic reasons. Modelling of the contraceptive effects projected to the year 2025 show that 
without the vaccine implementation, based on the average inter-calving interval per individual female, assuming no major episodic events such as drought, disease or fire, and considering a $1 \%$ age-related mortality, the GMPGR population would have doubled twice (Bertschinger et al. 2017:14; Delsink et al. 2007:25-30).

An interesting observation was the effect of number of treatments on the time taken to treat all the elephants. During the primary immunisation, which was carried out from the ground, an average of six cows per day were remotely darted with the vaccine using a Dan-Inject ${ }^{\circledR}$ dart gun (Delsink et al. 2006:403-405). This gradually decreased to an average of only 1.5 cows darted per day. The progressive increase in time taken to treat the cows from the ground was attributed to avoidance display when they recognised the sound of the darting vehicle (Delsink et al. 2013:52-74). A combination of ground and aerial darting in 2003 increased the average number to four cows per day (6 animals darted from the vehicle and 17 from the helicopter) and, in 2004, 12 per day ( 2 animals darted from the vehicle and 21 from the helicopter) (Delsink et al. 2007:25-30). From 2005 and onwards, only aerial vaccinations were conducted, and 23 cows were darted in 30-60 min using the Pneu-dart ${ }^{\circledR}$ dart gun. Because less time is spent on treatment, darting efficacy is improved and disturbance of the elephants is reduced, aerial darting has been the method of choice for subsequent treatments and for all new reserves.

\section{Additional population control projects}

From 2002 to 2005, another six game reserves joined the pZPimmunocontraception programme. The main objective of each reserve was to reduce the calving rate of cows $\geq 12$ years of age to zero during the first few years. The reserve sizes, total elephant population, annual percentage of cows calving and number of cows treated in Year 1 varied from 8000 to
35000 ha, 9 to 117 elephants, $16.7 \%$ to $25 \%$ and 4 to 35 cows, respectively (Table 1; Bertschinger et al. 2012:95-102). The total number of cows treated, including GMPGR (game reserve 1), was 108 during Year 1 of their respective programmes. All cows were individually identified, and during Year 1 each cow received a primary treatment with either $600 \mu \mathrm{g}$ or $400 \mu \mathrm{g}$ pZP with FCMA and two boosters of $400 \mu \mathrm{g}$ or $200 \mu \mathrm{g}$ with FIA. The cows in these new reserves were treated using aerial darting. From 2004, following the horse protocol (Kirkpatrick et al. 1995:411-418), a single booster containing $200 \mu \mathrm{g}$ pZP was used during Year 1 followed by annual boosters of $200 \mu \mathrm{g}$ pZP.

Table 2 gives the total number of cows treated in the seven reserves from Years 1 to 4 and then six reserves in Years 5 and 6 (Bertschinger et al. 2012:95-102). Reserves were normalised according to the year of contraception commencement. Like GMPGR, cows continued to calve during Years 1 and 2 (35 and 22 calves, respectively). During Years 3-6, no calves were born demonstrating a contraceptive efficacy of $100 \%$. Extrapolating backwards from date of calving 22 months, the stage of pregnancy at the time of primary immunisation was evenly distributed (18, 20 and 19 cows in first, second and third trimesters, respectively). These were apparently normal healthy calves, which once again suggested the safety of the vaccine during pregnancy. Also important was the stage of treatment at which immunocontraception was achieved. Using calving dates once again, 55 cows conceived prior to the primary, 1 around the time of the primary and 1 between the primary and first booster immunisation. Subsequent to the first booster, no conceptions occurred (Bertschinger et al. 2012:95-102). A side effect that was observed in some cows during the next round of treatment was the development of swellings (presumed to be subcutaneous) that later formed scars on the rumps (gluteal muscle mass) of the animals. These swellings resolved spontaneously and so far have not been

TABLE 1: Elephant populations with individually treated cows on seven game private game reserves.

\begin{tabular}{|c|c|c|c|c|c|c|c|}
\hline \multirow[t]{2}{*}{ Variables } & \multicolumn{7}{|c|}{ Game reserves } \\
\hline & $1 \dagger$ & 2 & 3 & 4 & 5 & 6 & 7 \\
\hline Size (ha) & 24500 & 8000 & 22800 & 8000 & 11548 & 35000 & 8461 \\
\hline Population size Year $1(n)$ & 53 & 11 & 92 & 10 & 35 & 117 & 9 \\
\hline Start of treatment & June 2000 & May 2002 & July 2004 & July 2004 & May 2005 & September 2005 & October 2005 \\
\hline Cows treated in Year $1(n)$ & 23 & 4 & 19 & 4 & 19 & 35 & 4 \\
\hline Age range of cows (years) Year 1 & $12-50$ & $13-16$ & $10-35$ & $19-25$ & $6-31$ & $9-44$ & $10-40$ \\
\hline
\end{tabular}

(\%) before treatment ( $n$ years)

Source: Modified according to Bertschinger, H.J., Delsink, A., Kirkpatrick, J., Van Altena, J., Ahlers, M., Dickerson, T. et al., 2012, 'Porcine Zona Pellucida immunocontraception of African elephants (Loxodonta africana): Beyond the experimental stage', in J. Cain, III \& J. Marshal (eds.), IVth International Wildlife Management Congress - Cooperative Wildlife Management Across Borders: Learning in the Face of Change, The Wildlife Society, Durban, 9-12th July, pp. 95-102.

$\dagger$, Game Reserve 1 = Greater Makalali Private Game Reserve (GMPGR).

TABLE 2: Number of game reserves, normalised according to year of commencement, and total number of cows immunised with porcine zona pellucida vaccine and number and percentage of calves born from one to six years.

\begin{tabular}{lccccc}
\hline Variables & Year 1 & Year 2 & Year 3 & Year 4 & Year 5 \\
\hline Number of reserves & 7 & 7 & 7 & 7 & 6 \\
Cows treated & 108 & 108 & 108 & 107 & 103 \\
Calves born & 38 & 24 & 0 & 0 & 0 \\
Overall calving percentage $(\%) \dagger$ & 35.2 & 22.2 & 0 & 0 & 0 \\
\hline
\end{tabular}

Source: Modified according to Bertschinger, H.J., Delsink, A., Kirkpatrick, J., Van Altena, J., Ahlers, M., Dickerson, T. et al., 2012, 'Porcine Zona Pellucida immunocontraception of African elephants (Loxodonta africana): Beyond the experimental stage', in J. Cain, III \& J. Marshal (eds.), IVth International Wildlife Management Congress - Cooperative Wildlife Management Across Borders: Learning in the Face of Change, The Wildlife Society, Durban, 9-12th July, pp. 95-102.

$\dagger$, Calves per 100 cows per annum. 
associated with visible lameness nor have any required treatment (Bertschinger et al. 2008:257-328). Reducing the pZP dose from $600 \mu \mathrm{g}$ to $400 \mu \mathrm{g}$ for primary and $400 \mu \mathrm{g}$ to $200 \mu \mathrm{g}$ for boosters as well as only applying a single booster in Year 1 had no effect on the $100 \%$ efficacy achieved. It should however be stressed that these were all individually identified cows.

Since 2005, another 13 private and 5 provincial reserves, and 1 national park have joined the immunocontraception programme with a current total of more than 800 cows on treatment (Bertschinger et al. 2017:8-21). The populations of many of these reserves are too large to apply individual cow recognition and thus associated treatment on an individual basis. Instead, blanket treatment is being used and to facilitate location and treatment of herds, radio or global positioning system (GPS) collars on at least one family member are being used in most reserves. In addition, mark and inject darts (Pneu-dart ${ }^{\circledR}$ ) facilitate the identification of cows treated during the immunisation process. Except for two reserves, it is too soon to comment on the results from the large reserves. As expected, blanket treatment does not induce a $100 \%$ contraceptive efficacy rate as some cows will likely be missed during the vaccination process.

Tembe Elephant Park started their programme in 2007 when approximately 70 cows out of a total population of 200 elephants were treated. The population had grown from 54 in 1993 to around 200 in 2007 and from 2004 to 2007 the number of calves born varied from 10 to 14 per annum. From 2008 to 2014 , 8, 10, 5, 3, 3, 4 and 4 calves were born. Immunocontraception had a clear impact on calving rate despite only two treatments being applied during the first year (Bertschinger et al. 2013:S150).

Two portions of Addo Elephant Park (Nyati and Kuzuko) started their programme in 2013. The annual population growth rate of these two reserves prior to treatment were $5 \%$ and $2 \%$, respectively, and approximately 50 cows out of a population of 125-130 elephants were treated annually. Three treatments were applied in Year 1 followed by annual boosters. In 2016, no calves were born (A. Gaylard, pers. comm., Regional Ecologist, Frontier, South African National Parks, Knysna). The possible explanation for the improved efficacy compared to Tembe Elephant Park was the use of three treatments in Year 1. Whether or not two or three treatments during Year 1 are used depends on the objectives of the elephant management plan of the reserve. The addition of a second booster will clearly have financial implications.

\section{Current questions and answers regarding elephant immunocontraception \\ Reversibility}

Reversibility is most easily determined by pregnancy or calving rate/calves born during the post-treatment period. Alternatively, faecal progesterone metabolite concentrations (FPMC) provide a measure of ovarian functionality and thus potential reversal of effect.

The first trial in the KNP demonstrated short-term reversibility of immunocontraception in terms of pregnancies recorded in three cows (see the section 'First porcine zona pellucida immunocontraception field study in the Kruger National Park'; Fayrer-Hosken et al. 2000:149). Table 3 shows the reversals in terms of conceptions extrapolated from calving dates in cows at GMPGR (Bertschinger et al. 2017:821; Delsink et al. 2013:52-74). Extrapolated from calving dates, four of five younger cows (25-30 years of age) treated for 4-6 years reversed and conceived 18-96 months after the last treatment. Another 3 cows, treated for 12-13 years, had not conceived 36-48 months after the last treatment. Of the four oldest cows $(>50->60)$ that had been treated for 6 to 12 years, one (Yvonne) had not conceived at 108 months after the last treatment. Another cow (Toni) showed signs of a recent pregnancy when she was euthanased 60 months after the last treatment. Presumably she had aborted. Another two very old cows (Holey Ear and Kwatile) had not conceived 48 and 120 months, respectively, after the last treatment. Kwatile died of old age and on post mortem her ovaries contained few follicles. In horses, Kirkpatrick et al. (1995:411-418) established a relationship between the duration of annual treatments and interval until reversal. Maybe as a result of small numbers, the same trend could not be observed in elephants. An additional factor that should be considered with elephants is age. Although elephant cows may reproduce well into their 60s, there is a definite decrease in the number of ovarian follicles with age with some cows showing ovarian

TABLE 3: Contraception reversal or non-reversal of Greater Makalali Private Game Reserve elephant cows after 2-13 years of annual porcine zona pellucida treatment.

\begin{tabular}{|c|c|c|c|c|}
\hline Cow & Duration of treatment (years) & Age at last data collection point (years) & Interval from last treatment to conception $\dagger$ (months) & Comments \\
\hline Bubbles & 2 & $\approx 25$ & 18 & - \\
\hline Connie & 4 & $\approx 25$ & 28 & - \\
\hline Smelly & 6 & $\approx 35$ & 18 & - \\
\hline Tiny & 6 & $\approx 30$ & 96 & - \\
\hline Holey Ear & 12 & $\approx 60$ & None after 48 & - \\
\hline Dracula & 12 & $>50$ & None after 48 & - \\
\hline Tinkerbell & 13 & $\approx 25$ & None after 36 & - \\
\hline Toni & 12 & $>50$ & $\begin{array}{l}60 \\
\text { Probably aborted }\end{array}$ & $\begin{array}{l}\text { Euthanased - leg injury. } \\
\text { Immobilised twice for treatment. }\end{array}$ \\
\hline Yvonne & 6 & $\approx 60$ & None after 108 & Age related? \\
\hline Kwatile & 10 & $\approx 64$ & None after 120 & $\begin{array}{l}\text { Died of old age. } \\
\text { Few follicles still present. }\end{array}$ \\
\hline
\end{tabular}

$\dagger$, Calving date minus gestation period of 22 months. 
senescence between 55 and 65 years of age (Stansfield, Nöthling \& Allen 2013:1165-1173). A failure of reversal in old cows may thus be because of ovarian senescence rather than the effects of ZP-immunocontraception. Certainly there is a need to conduct more research regarding reversibility and duration of treatment in elephants.

\section{Faecal progesterone metabolite concentrations as indicators of cyclic ovarian activity}

Ovarian activity can be monitored by linear assessment of FPMC, which change as cyclic corpora lutea are formed and undergo regression during sequential oestrous cycles. The average length of the oestrous cycle of the African elephant is 15 weeks and consists of a follicular phase (4-6 weeks) and a luteal phase (6-12 weeks) (Brown 2000:347367). Failure to conceive will lead to repeated oestrous cycles and, if monitored using FPMC, would be evident as cyclic increases and decreases in this metabolite. If ovarian function of pZP-treated elephant cows is not affected, repeated FPMC peaks should also be observed starting 6-24 months after calving. Two studies on pZP-treated cows were carried out using FPMC. A 12-month study was carried out on a reserve where 10 adult cows had been treated with pZP for two years (three treatments during Year 1 and annual boosters) (Ahlers et al. 2012:77-85). Faecal sampling commenced two years after the primary vaccine. Nine cows showed regular or irregular cycles and one cow was acyclic six months after calving. A significant effect of season on FPMC was established with concentration in the dry months being lower than the wet months of the year (Ahlers et al. 2012:77-85). A second study lasting 13 months was carried out where nine cows had been previously treated with pZP for four years and discontinued for two years prior to commencing sampling (Benavides Valades et al. 2012:1-10). Another four untreated cows served as controls. An adult bull was not present on the reserve. All cows showed at least one cycle during observation period and once again there was a significant effect of season on FPMC (Benavides Valades et al. 2012:1-10). This effect included the control animals. The findings of both studies indicated that all treated cows showed at least one luteal cycle following treatment for either two or four years. They also demonstrated a significant effect of season on FPMC and that seasonal anoestrus in elephant cows, depending on rainfall and thus resources, is possible. Thus, contrary to previous expectations, pZP-treated cows will not necessarily cycle all year round, but are likely to show periods of anoestrus during the dry months and especially when severe droughts occur (Bertschinger et al. 2012:95-102).

\section{Behavioural effects}

Following administration of the vaccine from a vehicle or on foot, short-term avoidance behaviour of the darting team was observed. However, the elephants were only wary of the darting team on the game-viewing vehicles and not of guests on similar vehicles. Once aerial administration was implemented, spatial avoidance was assessed by analysis of core home range use before, during and after vaccine administration. In the short term, the elephant core home range use shifted during vaccine administration in response to the helicopter, but in the long term, the elephants returned to their core home range (Delsink et al. 2013:52-74).

Although more harassment of cows by bulls owing to more frequently cycling cows was expected, there was no increased trend for bulls to associate with females (Ahlers et al. 2012:7785; Delsink et al. 2013:52-74; Druce et al. 2013:180-187). Bull hierarchy remained stable with dominant bulls dominating all courtship and mating behaviour. Cow mate selection remained intact with dominant bulls selected above others. The reduced number of calves had no impact on various aspects of family unit behaviour, integrity and movement. Intra- and inter-herd associations remained intact, no intra-or inter-species aggression was observed and the integrity of herds remained stable and strong. Despite demographic changes and the resultant change in nutritional requirements of non-lactating and non-pregnant cows, there was no change in spatial range use (Delsink et al. 2013:52-74; Druce et al. 2013:180-187).

\section{Recombinant zona pellucida vaccine as a possible alternative}

The manufacturing process of native pZP is laborious, expensive and yields small amounts of vaccine. As an animal product, the cross-border movement of vaccine to other countries with elephants (African or Asian) is difficult and in some cases impossible. In collaboration with the Council of Scientific and Industrial Research (CSIR), the University of Pretoria has developed two synthetic bacterial zona pellucida proteins that have proven to be equally effective as a contraceptive in donkeys (French et al. 2017). Currently, the contraceptive efficacy of the proteins in combination with non-Freund's adjuvants with less injection site reactions is being tested in horses and donkeys. If this proves to be effective, the protein-adjuvant formulation should be tested in elephant cows.

\section{Conclusions}

Some of the gaps in the knowledge identified in the 2008 Elephant Assessment process have been closed. Ultimately, pZP mimics natural episodic events such as drought where inter-calving intervals are lengthened. The work reviewed here provided evidence that pZP-immunocontraception delivered on an individual cow basis induced a contraception efficacy of $100 \%$. It was shown to be safe in the target animal and foetus, the only visible side effects being injection site reactions. Based on the evidence to date, with application in larger populations where individual cow treatment is not possible, population control can also be achieved. In our opinion, even if some moderate consequences exist, the alternatives are often worse (e.g. over-population, culling) 
and thus, after 20 years, pZP can be considered as a reliable and humane method for elephant population control. Further studies are needed to investigate long-term ( $>20$ years) effects on reversibility, social structure and behaviour and individual behaviour of treated elephant cows.

\section{Acknowledgements}

The authors would like to acknowledge the support received from the University of Pretoria, The Humane Society International, United States Fish and Wildlife Services and Technology Innovation Agency. They thank all the private, provincial game reserves and South African National Parks for taking part in this project and the veterinarians responsible for administration of the vaccine.

\section{Competing interests}

The authors declare that they have no financial or personal relationships that may have inappropriately influenced them in writing this article.

\section{Authors' contributions}

H.J.B. and A.D. were involved in the writing of the paper and in pZP-immunocontraceptive studies throughout from 1995 to 2017 and 2000 to 2017, respectively. J.J.v.A. was involved in the pZP-immunocontraceptive behavioural research from 1995 to 2004 and contributed to a number of papers on the practical application of the topic. J.F.K. was involved in the pZP-immunocontraceptive research from 1995 to 2004 and contributed to a number of papers on the topic.

\section{References}

Ahlers, M.J., Ganswindt, A., Münscher, S. \& Bertschinger, H.J., 2012, 'Fecal 20-oxopregnane concentrations in free-ranging African elephants (Loxodonta africana) treated with porcine zona pellucida vaccine', Theriogenology $78,77-85$. https:// doi.org/10.1016/j.theriogenology.2012.01.023

Bagavant, H., Adams, S., Terranova, P., Chang, A., Kraemer, F.W., Lou, Y. et al., 1999, 'Autoimmune ovarian inflammation triggered by proinflammatory (Th1) T cells is compatible with normal ovarian function in mice, Biology of Reproduction 61 635-642. https://doi.org/10.1095/biolreprod61.3.635

Benavides Valades, G., Ganswindt, G., Annandale, H., Schulman, M.L. \& Bertschinger H.J., 2012, 'Non-invasive assessment of the reproductive cycle in free-ranging female African elephants (Loxodonta africana) treated with a gonadotropinreleasing hormone (GnRH) vaccine for inducing anoestrus', Reproductive Biology and Endocrinology 10, 1-10. https://doi.org/10.1186/1477-7827-10-63

Bertschinger, H.J. \& Caldwell, P., 2016, 'Fertility suppression of some wildlife species in southern Africa - A review', Reproduction in Domestic Animals 51(Suppl 1), 18-24. https://doi.org/10.1111/rda.12783

Bertschinger, H.J., Delsink, A., Kirkpatrick, J., Van Altena, J., Ahlers, M., Dickerson, T. et al., 2012, 'Porcine Zona Pellucida immunocontraception of African elephants (Loxodonta africana): Beyond the experimental stage', in J. Cain, III \& J. Marshal (eds.), IVth International Wildlife Management Congress - Cooperative Wildlife Management Across Borders: Learning in the Face of Change, The Wildlife Society, Management Across Borders: Learni
Durban, 9-12th July, pp. 95-102.

Bertschinger, H.J., Delsink, A., Schulman, M. \& Kirkpatrick, J., 2017, 'Development and current status of African elephant (Loxodonta africana) immunocontraception using the porcine zona pellucida (PZP) vaccine in South Africa', in The 8th International Conference on Wildlife Fertility Control, Kellogg Conference Hotel, International Conference on Wildlife Fertility Control, Kell
Gallaudet University, Washington, DC, 18-21st July, p. 14

Bertschinger, H.J., Delsink, A., Van Altena, J.J., Kirkpatrick, J., Killian, H., Ganswindt A. et al., 2008, 'Chapter 6: Reproductive control of elephants', in R.J. Scholes \& K.G. Mennel (eds.), Elephant management: A scientific assessment for South Africa, pp. 257-328, Wits University Press, Johannesburg, South Africa.

Bertschinger, H.J., Matthews, W.S., De Goede, N., Hanekom, C., Cooper, D., Müller, L. et al., 2013, 'The Tembe Elephant Park (Loxodonta africana) immunocontraception story', Journal of Zoo and Wildlife Medicine 44(4 Suppl), S150.
Brown, J.L., 2000, 'Reproductive endocrine monitoring of elephants: An essential tool for assisting captive management', Zoo Biology 19, 347-367. https://doi. org/10.1002/1098-2361(2000)19:5<347::AID-ZOO6>3.0.CO;2-V

Castiglione, F., Mantile, F., De Berardinis, P. \& Prisco, A., 2012, 'How the interval between prime and boost injection affects the immune response in a computational model of the immune system', Computational and Mathematical Methods in Medicine 2012, Article ID 842329, 1-9.

Caughley, G., 1976, 'The elephant problem - An alternative hypothesis', East African Wildlife Journal 14, 265-283. https://doi.org/10.1111/j.1365-2028.1976. tb00242.x

Curtis, P.D., Richmond, M.E., Miller, L.A. \& Quimby, F.W., 2007, 'Pathophysiology of white-tailed deer vaccinated with porcine zona pellucida immunocontraceptive', Vaccine 25, 4623-4630. https://doi.org/10.1016/j.vaccine.2007.03.033

Delsink, A. \& Kirkpatrick, J.F. (Compilers), 2012, Free-ranging African elephant immunocontraception: A new paradigm for elephant management, Trident Press, Cape Town, pp. 1-26.

Delsink, A.K., Kirkpatrick, J., Van Altena, J.J., Bertschinger, H., Ferreira, S. \& Slotow, R., 2013, 'Lack of spatial and behavioural responses to immunocontraception application in African elephants (Loxodonta africana)', Journal of Zoo and Wildlife Medicine 44, S52-S74. https://doi.org/10.1638/1042-7260-44. 4S.S52

Delsink, A.K., Van Altena, J.J., Grobler, D., Bertschinger, H.J., Kirkpartick, J.F. \& Slotow, R., 2007, "Implementing immunocontraception in free-ranging African elephant at Makalali Conservancy', Journal of the South African Veterinary Association 78(1), 25-30. https://doi.org/10.4102/jsava.v78i1.282

Delsink, A.K., Van Altena, J.J., Grobler, D., Kirkpatrick, J., Bertschinger, H. \& Slotow, R. 2006, 'Regulation of a small, discrete African elephant population through immunocontraception in the Makalali Conservancy, Limpopo, South Africa', South African Journal of Science 102, 403-405.

Druce, H., Mackey, R., Pretorius, K. \& Slotow, R., 2013, 'The intermediate-term effects of PZP immunocontraception: Behavioural monitoring of the treated elephant females and associated family groups', Animal Conservation 16, 180-187. https:// doi.org/10.1111/j.1469-1795.2012.00583.x

Dunbar, B.S., Waldrip, N.J. \& Hendrik, J.L., 1980, 'Isolation, physiochemical properties, and macromolecular composition of zona pellucid from porcine oocytes', Biochemistry 19, 356-365. https://doi.org/10.1021/bi00543a017

Fayrer-Hosken, R.A., Bertschinger, H.J., Kirkpatrick, J.F., Grobler, D., Lambreski, N., Honneyman, G. et al., 1999, 'Contraceptive potential of the porcine zona pellucida vaccine in the African elephant (Loxodonta africana)', Theriogenology 52, 835846. https://doi.org/10.1016/S0093-691X(99)00176-4

Fayrer-Hosken, R.A., Grobler, D., Van Altena, J.J., Bertschinger, H.J. \& Kirkpatrick, J.F., 2000, 'Immunocontraception of African elephants', Nature 407, 149. https://doi. org/10.1038/35025136

French, H., Peterson, E., Ambrosia, R., Bertschinger, H., Schulman, M., Crampton, M. et al., 2017, 'Porcine and recombinant zona pellucida vaccines as immunocontraceptives for donkeys in the Caribbean', in The 8th Internationa Conference on Wildlife Fertility Control, Kellogg Conference Hotel, Gallaudet University, Washington, DC, 18-21st July.

Kirkpatrick, J.F., Liu, I., Turner, J., Naugle, R. \& Keiper, R., 1992, 'Long-term effects of porcine zonae pellucidae immunocontraception on ovarian function in feral horses (Equus caballus)', Journal of Reproduction and Fertility 94, 437-444. https://doi.org/10.1530/jrf.0.0940437

Kirkpatrick, J.F, Lyda, R.O. \& Frank, K.M., 2011, 'Contraceptive vaccines for wildlife: A review', American Journal of Reproductive Immunology 66, 40-50. https://doi. org/10.1111/j.1600-0897.2011.01003.x

Kirkpatrick, J.F., Naugle, R., Liu, I., Bernoco, M. \& Turner, J., Jr., 1995, 'Effects of seven consecutive years of porcine zona pellucida contraception on ovarian function in feral mares', Biology of Reproduction Monograph 1, 411-418.

Kirkpatrick, J.F. \& Turner, A., 2002, 'Reversibility of action and safety during pregnancy of immunizing against porcine zona pellucida in wild mares (Equus caballus)', Reproduction 60, 197-202.

Kirkpatrick, J.F. \& Turner, A., 2007, 'Immunocontraception and increased longevity in equids', Zoo Biology 25, 1-8. https://doi.org/10.1002/zoo.20109

Kirkpatrick, J.F. \& Turner, A., 2008, 'Achieving population goals in a long-lived wildlife species (Equus caballus) with contraception', Wildlife Research 35, 513-519. https://doi.org/10.1071/WR07106

Lane, V.M., Liu, I.K., Casey, K., Van Leeuwen, E.M., Flanagan, D.R., Murata, K et al, 2007, 'Inoculation of female American black bears (Ursus americanus) with partially purified porcine zona pellucidae limits cub production', Reproduction and Fertility Development 19(5), 617-625. https://doi.org/10.1071/RD06154

Liu, I.K., Bernoco, M. \& Feldman, M., 1989, 'Contraception in mares heteroimmunized with pig zonae pellucidae', Journal of Reproduction and Fertility 85, 19-29. https://doi.org/10.1530/jrf.0.0850019

Lyda, R.O., Frank, K.M., Wallace, R. \& Kirkpatrick, J.F, 2013, 'Immunocontraception of captive exotic species: V. prolonged antibody titers in Dall sheep (Ovis Dalli Dalli) and domestic goats (Capra Hircus) immunized with porcine zona pellucida', Journal of Zoo and Wildlife Medicine 44(4 Suppl), S21-S25. https://doi. org/10.1638/1042-7260-44.4S.S21

Mackey, R.L., Page, B.R., Duffy, D. \& Slotow, R., 2006, 'Modelling elephant population growth in small, fenced, South Africa reserves', South African Journal of Wildlife Management 36, 33-43.

Millar, S.E., Chamow, S.M., Baur, A.W., Oliver, C., Robey, F. \& Dean, J., 1989, 'Vaccination with a synthetic zona pellucida peptide produces long-term contraception in female mice', Science 246, 935-938. https://doi.org/10.1126/science.2479101 
Owen-Smith, RN., 1988, 'Megaherbivores: The influence of very large body size on ecology', in R.S.K. Barnes, H.J.B. Birks, E.F. Connor \& R.T. Paine (eds.), Cambridge ecology', in R.S.K. Barnes, H.J.B. Birks, E.F. Connor \& R.T. Paine
studies in ecology, p. 369, Cambridge University Press, New York.

Paterson, M., Wilson, M., Jennings, Z., Van Duin, M. \& Aitken R., 1999, 'Design and evaluation of a ZP3 peptide vaccine in a homologous primate model', Molecular Human Reproduction 5, 342-352. https://doi.org/10.1093/molehr/5.4.342

Shideler, S.E., Stoops, M.A., Gee, N.A., Howell, J.L. \& B.L. Lasley, B.L., 2002, 'Use of porcine zona pellucida (pZP) vaccine as a contraceptive agent in free-ranging Tule elk (Cervus elaphus nannodes)', Reproduction 60, 169-176.
Stansfield, F.J., Nöthling, J.O. \& Allen, W.R., 2013, 'The progression of small-follicle reserves in the ovaries of wild African elephants (Loxodonta africana) from puberty to reproductive senescence', Reproduction, Fertility and Development 25 1165-1173. https://doi.org/10.1071/RD12296

Van Aarde, R.J., Ferreira, S.M., Jackson, T., Page, B., De Beer, Y., Gough, K. et al., 2008, 'Chapter 2: Elephant population biology and ecology', in R.J. Scholes \& K.G. Mennel (eds.), Elephant management: A scientific assessment for South Africa, pp. 84-145, Wits University Press, Johannesburg, South Africa. 